its refractive power. For the second liquid Mr. Ahrens has succeeded in finding in the paraffin series a white oil which is a suitable material in its mechanical as well as in its optical properties. It has not, however, the same mean refractive index as methyl salicylate, so therefore, for a direct-vision prism, the end faces cannot be square to the principal axis of the transmitted light. Their obliquity, however, is not great-not more than $15^{\circ}$ if the refracting angle of the middle prismatic cell is from $120^{\circ}$ to $125^{\circ}$. The dispersion of these prisms is very good, and there is much less absorption of the blue end of the spectrum than is usually found with a bisulphide or flint-glass prism. The writer, in a rough comparison of one of the Ahrens biliquid prisms with a Wernicke prism and a $60^{\circ}$ bisulphide prism, found the following angular dispersions between

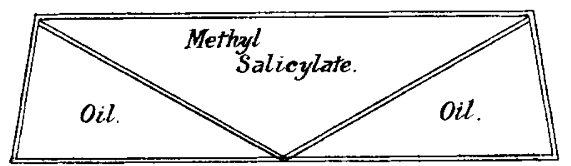

Ahrens's Biliquid Direct-vision Prism.

the $\mathrm{C}$ and $\mathrm{F}$ hydrogen lines:-bisulphide of carbon prism, $3^{\circ} 27^{\prime}$; Wernicke prism, $3^{\circ} 6^{\prime}$; Ahrens prism, $3^{\circ} 12^{\prime}$.

If direct-vision is not desired, a prism of high dispersion can be made on the same biliquid plan by constructing a glass cell with the end faces at about $30^{\circ}$ to the line of sight, and with internal oblique partitions at from $20^{\circ}$ to $24^{\circ}$ to the line of sight, dividing the whole into three prismatic chambers, the two outer of which are filled with methyl salicylate and the middle one with the white oil. This prism has marked superiority over a flint-glass prism of equal size. It must not, of course, be forgotten that all liquid prisms are unsuitable for fine definition of the spectral lines owing to the change of refractive index in the liquid when the temperature rises.

The biliquid prism is being put on the market by $\mathrm{Mr}$. Pillischer.

\section{THE REFORM OF MATHEMATICAL AND SCIENCE TEACHING IN GERMANY.'}

THE revolt against formal culture which characterised mathematical instruction has within the last decade produced a large bibliography in English, French, and German, and inspired systematic inquiry into possible and needful reform. The movement has been assisted in Germany by an extension of the privileges of the Gymnasium to the Realgymnasium and the Oberrealschule, which in time may share the prestige of the Gymnasium and win for the exact sciences a place ebenbürtig with the classics.

When the Reformschulen were founded to provide a common foundation for all pupils in nine-class schools between the ages of nine and twelve, engineers were pronouncedly favourable, thinking that the exact sciences would benefit, and that an Einheitsmittelschule (secondary school with uniform curriculum) was in sight. But they were doubly disappointed; the classics have benefited, and the Einheitsmittelschule is condemned for systematic perfection.

Reform of mathematical and science teaching depends closely on the inexorable demands of civilisation, and for the understanding of modern culture a proper grasp of the meaning of a function is considered indispensable. On this account it is proposed to include analytical geometry and the calculus in the work of the nine-class schools. As no more time can be allotted to mathematics, any relief must come from further pruning of the syllabus. Hence elementary mathematics must be relieved of its lumber, the desire to achieve systematic perfection must be left unfulfilled, pedantic thoroughness must be killed by ridicule, and the exclusively deductive form abandoned, more value being attached to intuition than to a cunning use of the syllogism. Though mathematicians attack the isolation of their subject, they do not advocate Fachbildung (professional studies) in secondary schools. Pro-

1 Abstract of paper read at the meeting of the Edinburgh Mathematical Society on November it by Mr. A. J. Presslant.

NO. 2 I 43 , VOL. 85$]$ fessional bodies have always protested against it, and the protest has been taken to indicate the attitude of Trade Unions also. Nevertheless, German universities are trying to give the teacher an acquaintance with practical applications and arrange courses in applied mathematics or recognise attendance at technical high schools. The courses include descriptive geometry, mathematical methods of technical mechanics, surveying, life assurance, and laboratory work.

The introduction of practical work in the teaching of physics is urgently needed. It is provided in the best Prussian schools and in South Germany, notably at Munich, it forms part of the primary syllabus during the last two years. A statistical inquiry showed that 75 per cent., at least, of Prussian secondary schools desired facilities for experimental work, whilst only about thirty possessed them.

The minimum amount of time demanded is seven hours per week for science-physics, chemistry, biology, and geography-and four for mathematics. If proposals for introducing specialisation in the last three years are entertained, further hours may fall to the lot of the exact sciences.

The reintroduction of biology, which disappeared in I879 as a result of the writings of Darwin and Haeckel, is being advocated as a training of the powers of observation, in which the German freshman is said to be woefully deficient, and as an exercise in the use of the microscope. Geography comprises economic geology, Erdkunde, and astronomy, as well as commercial products. To bring it into organic connection with mathematics, courses of lectures on the interconnection of mathematics are being projected.

Matters are still in an indefinite position, but there are indications that the Cambridge Congress of 1912 will mark the beginning of a new era. lt is to be hoped, for our sakes, that the results of this congress can be laid before the Consultative Committee of the Board of Education to be recommended for adoption throughout the Empire.

\section{UNIVERSITY AND EDUCATIONAL} INTELLIGENCE.

Birmingham.-Mr. John Dale has been awarded the Walter Myers studentship for a further period of one year, having proved himself a student of exceptional merit. An award of the same studentship for the present year has been made to $\mathrm{Mr}$. Cranston Walker. The value of the studentship is $150 l$. per annum, and it must be used for research in pathology or clinical medicine at some German university. Mr. Dale, the first holder, is working at Hamburg, and $\mathrm{Mr}$. Cranston Walker is at the University of Freiburg, in Baden. The holder must possess a degree in science in addition to degrees in medicine and surgery.

Cambridge.-An election to an Isaac Newton studentship will be held in the Lent term, igri. It will be the duty of the student to devote himself during the tenure of his studentship to study or research in some branch of astronomy or of physical optics, according to a course proposed by himself and approved by the electors. The student's course of study or research must be pursued at Cambridge. The studentship will be tenable for the term of three years from April I5, I9II. The emolument of the student will be $200 l$. per annum. Candidates for the studentship are invited to send in their ipplications to the Vice-Chancello between January 16 and 26, I9I 1 , together with testimonials and such other evidence as to their qualifications and their proposed course of study or research as they may think fit.

Mr. A. E. Shipley, F.R.S., master of Christ's College, has been nominated by the general board of studies as a member of the board of electors to the professorship of zoology and comparative anatomy in succession to the late Mr. J. W. Clark; and Prof. W. J. Pope, F.R.S. has been nominated by the council of the Senate a member of the board of electors to the Allen scholarship.

OXFORD.-On November 22 another stage was reached in the discussion of the changes proposed by the Hebdomadal Council at the instance of the Chancellor of 